\title{
Effects of adrenal demedullation and stria terminalis lesions on retention of an inhibitory avoidance response
}

\author{
K. C. LIANG \\ University of California, Invine, California, \\ and The National Taiwan University, Taipei, Taiwan \\ and \\ JAMES L. McGAUGH \\ University of California, Irvine, California
}

\begin{abstract}
The present study investigated the effects of adrenal demedullation and/or lesions of the stria terminalis (ST) on retention of an inhibitory avoidance response. The results of Experiment 1 indicate that adrenal demedullation results in impaired retention when low footshock is used for training. The results of Experiment 2 indicate that ST lesions produce, at best, only a mild retention deficit. The results of Experiment 3 indicate that adrenal demedullation does not potentiate the effect of ST lesions on retention.
\end{abstract}

Considerable evidence suggests that certain stressreleased hormones, such as adrenal epinephrine, are involved in the endogenous modulation of memory storage processes (for a review, see Gold \& Zornetzer, 1983, and McGaugh, 1983). Previous studies have shown that in both appetitive and avoidance learning tasks, systemic administration of epinephrine shortly after training improves retention under conditions in which animals would otherwise have poor memory (Gold \& van Buskirk, 1978; Liang, Bennett, \& McGaugh, 1985; Liang, Juler, \& McGaugh, 1986; Sternberg, Isaacs, Gold, \& McGaugh, 1985). On the basis of the findings that epinephrine is generally released into peripheral circulation by aversive training experiences (Gold, McCarty, \& Sternberg, 1982), it has been proposed that peripherally released epinephrine might modulate memory processing under naturally occurring circumstances (Gold \& McGaugh, 1977). However, in contrast to the extensive evidence that exogenous administration of epinephrine affects memory, studies of the effects of blocking peripheral adrenergic function have yielded conflicting results. Walsh and Palfai (1979) reported that syrosingopine, which depletes peripheral catecholamines, produces a norepinephrinereversible retention deficit in the inhibitory avoidance task. In contrast, systemic injections of various $\alpha$ - or $\beta$ adrenergic antagonists do not affect retention performance of rats or mice (Novack, Sternberg, \& McGaugh, 1984); Sternberg, Korol, Novack, \& McGaugh, 1986). Furthermore, although some studies have reported that learning

Supported by USPHS Grant MH12526 and Research Contract NOOO14 84-K-0391 from the Office of Naval Research. The authors' mailing address is: Center for the Neurobiology of Learning and Memory, University of California, Irvine, CA 92717. and retention are impaired by adrenal demedullation (Borrell, de Kloet, Versteeg, \& Bohus, 1983; Caldwell, 1962; Silva, 1974), other studies have failed to find such effects (Martinez, Rigter, \& van der Gugten, 1980; Martinez, Vasquez, et al., 1980; Moyer \& Bunnell, 1959; Silva, 1973). Experiment 1 was designed to address this issue further.

There is also extensive evidence suggesting that the amygdala is involved in memory processing. Animals with lesions in the amygdala, either alone or in combination with the hippocampus, show poor acquisition/retention performance in certain tasks (Liang et al., 1982; Mishkin, Malamut, \& Bachevalier, 1984; for a review, see Sarter \& Markowitsch, 1985). Posttraining stimulation of the amygdala by electrical or chemical means affects retention of various learned responses (Ellis \& Kesner, 1983; Gallagher, Kapp, Pascoe, \& Rapp, 1981; Gold, Macri, \& McGaugh, 1973). The memory modulatory function of the amygdala involves, at least partially, one of its major afferent-efferent pathways-the stria terminalis (ST): The amnestic effect of posttraining amygdala stimulation is readily attenuated by lesions of the ST or by injecting naloxone into the bed nucleus of the ST (Liang \& McGaugh, 1983a; Liang, Messing, \& McGaugh, 1983). In view of these findings, it is puzzling that most studies that have examined the influence of ST lesions on retention have generally failed to observe a significant effect (Liang \& McGaugh, 1983a, 1983b; McGaugh, Introini-Collison, Juler, \& Izquierdo, 1986; van Wimersma Greidanus, Croiset, Bakker, \& Bouman, 1979).

It is well established that the effects on memory of modulatory treatments depend upon parameters of the task and the treatment (Gold, Hankins, Edwards, Chester, \& 
McGaugh, 1975; Gold \& van Buskirk, 1978; Silva, 1974; Sternberg, Gold, \& McGaugh, 1983). Therefore, it seems possible that the inconsistent effects of ST lesions or adrenal demedullation on learning and memory may be related to the training conditions used. However, our recent findings suggest an alternative possibility: Bennett, Liang, and McGaugh (1985) have shown that, in both inhibitory and active avoidance tasks, retention performance is not significantly affected by implantation of electrodes into the amygdala or by adrenal demedullation if the animals received only one of these surgical treatments. However, retention performance is severely impaired in adrenal demedullated animals with implanted amygdala electrodes. Thus, as has been proposed for the adrenal cortex and the central noradrenergic system (Ogren \& Fuxe, 1977; Roberts \& Fibiger, 1976), the influences from the adrenal medulla and those from the amygdala might be cooperative and mutually compensating in the modulating memory formation processes. According to this point of view, ST lesions or adrenal demedullation alone would not affect memory. However, the two treatments combined might produce a significant retention deficit.

To address these questions, the present study examined the effect of ST lesions and adrenal demedullation, either alone or in combination, on retention of inhibitory avoidance training involving footshock of varying intensities.

\section{GENERAL METHODS}

\section{Subjects}

Male Sprague-Dawley rats (60-70 days old) were individually housed upon arrival and maintained on a 12/12 light/dark cycle (lights on at 7:00 a.m.) with food and water ad lib. In all, 222 rats were used in the present study.

\section{Surgeries}

Approximately 1 week after the rats' arrival, surgery was performed under sodium pentobarbital $(50 \mathrm{mg} / \mathrm{kg}$ ) anesthesia.

ST Lesions. Anesthetized rats were mounted on the stereotaxic instrument. After the skull was exposed and two burr holes were drilled in proper locations, a bipolar electrode was inserted into the brain aiming at the ST (coordinates: AP $-0.5 \mathrm{~mm}$, ML $\pm 2.4 \mathrm{~mm}$ from midline, DV $-4.0 \mathrm{~mm}$ from dura, nose bar at $+5.0 \mathrm{~mm}$ ). The electrode was made by twisting two stainless steel wires with the tips separated for about $0.5 \mathrm{~mm}$. The electrode was insulated except for $0.5 \mathrm{~mm}$ of the tip. The two STs were lesioned sequentially by radio frequency currents $(1.5 \mathrm{~V}, 20 \mathrm{sec}$, LM-3 lesion maker, Grass Instruments) passing through the electrode. Afterwards, the electrode was withdrawn and the burr holes were sealed with Gelfoam and bone wax. Sham ST operations used the same surgical procedures but no current was administered through the electrodes.

Adrenal Demedullation. To remove the adrenal medulla, an incision was made on the lateral side of the body wall caudal to the last rib. The adrenal gland was held with hemostats and slit with microdissecting scissors. The adrenal medulla was then removed and the cortex released back into the abdominal cavity. The muscle was sutured and the skin was clipped. Two adrenals were oper- ated sequentially. The sham adrenal operation followed the same procedure except that the gland was not slit. When both treatments were administered to the same animal, the adrenal surgery was performed 7-10 days after the ST surgery.

The animals were maintained on tetracycline water for 1 week following each surgery. One percent solution of sodium chloride was added to the tetracycline water for the adrenal demedullated rats to protect against any possible temporary impairment of adrenal cortex functioning.

\section{Behavioral Task}

Two weeks after the final surgery, animals were trained on an inhibitory avoidance task. The apparatus was a trough-shaped alley $(91 \mathrm{~cm}$ long, $15 \mathrm{~cm}$ high, $30 \mathrm{~cm}$ wide at the top, $6.4 \mathrm{~cm}$ wide at the bottom). The alley was divided by a sliding door into an illuminated compartment $(30 \mathrm{~cm}$ long) and a dark compartment $(61 \mathrm{~cm}$ long). On the day of training, the rat was placed into the illuminated compartment facing away from the door. As the rat turned around, the door was opened and the rat entered the dark compartment. As soon as the rat entered the dark side, the door was closed and an inescapable electric shock was administered through the floor. The shock intensities and durations used are specified in the procedure section of each experiment. The rat was returned to its home cage about $5 \mathrm{sec}$ after receiving the shock. On the retention test given $24 \mathrm{~h}$ later, the rat was again placed into the illuminated side; the latency of entering the dark compartment was taken as the retention score. If a rat did not step through in $600 \mathrm{sec}$, the testing was terminated and the ceiling score of 600 was assigned.

\section{Surgery Verifications}

At the conclusion of each experiment, the rats were sacrificed with an overdose of sodium pentobarbital. The adrenal glands of all adrenal demedullated (ADMX) rats and some of the shamoperated rats were removed and stored under $-80^{\circ} \mathrm{C}$ until the catecholamines were assayed. All the ST-lesioned rats were perfused through the heart by $0.9 \%$ saline followed by $10 \%$ Formalin. The brain was removed and stored in Formalin for at least $48 \mathrm{~h}$. The brain was then sectioned into $40-\mu \mathrm{m}$ slices through the lesion area. Brain slices taken through the lesioned area were stained with cresyl violet.

Adrenal catecholamines were assayed by high-performance liquid chromatography coupled with an electrochemical detection method. The procedure has been described in detail elsewhere (Martinez et al., 1983).

\section{EXPERIMENT 1}

\section{Procedure}

The first experiment examined the effect of adrenal demedullation on retention of the inhibitory avoidance response trained under various footshock conditions. Rats received operations and were trained and tested as described in the General Method section. In previous research, we had found no retention deficit in ADMX rats given a 1-mA training footshock. Therefore, to maximize the opportunity of observing an effect of adrenal demedullation, adrenal demedullated (ADMX) rats and sham-operated rats (Sham) were given one of the following training footshocks: $0.50,0.64$, or $0.75 \mathrm{~mA}$ for $1 \mathrm{sec}$.

\section{Results}

Retention performance and the number of subjects of the Sham and ADMX groups in the inhibitory avoidance task are shown in Figure 1. Throughout the study, the 


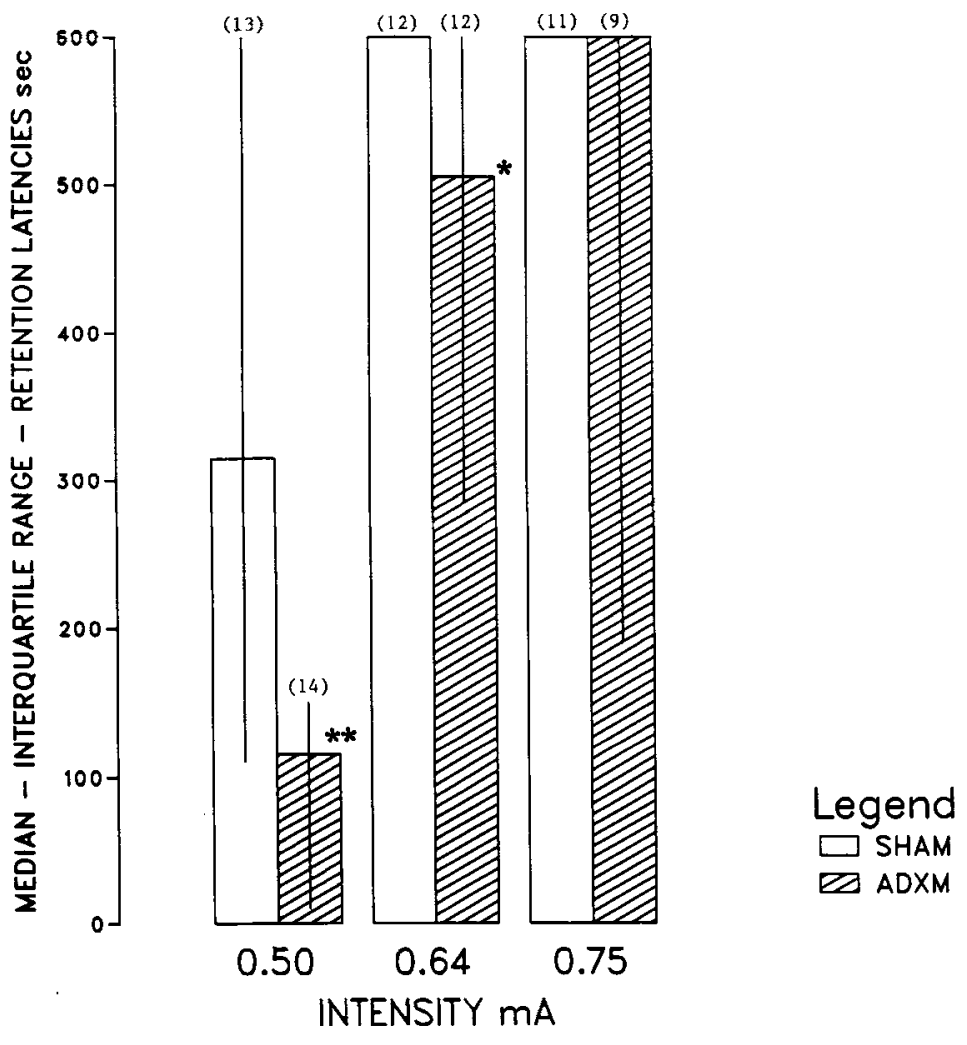

Figure 1. Effects of adrenal demedullation (ADMX) on inhibitory avoidance retention under various training footshocks. ${ }^{* *}=p<.01$ and $*=p<.05$ different from the adrenal sham-operated groups.

data were analyzed by nonparametric Kruskal-Wallis oneway analyses of variance and Mann-Whitney $U$ tests.

As the findings shown in Figure 1 indicate, in both the Sham and the ADMX rats, retention performance varied with the intensity of the training footshock (Kruskal-Wallis $H=7.62, p<.03$, for the Sham rats; $H=12.27$, $p<.005$, for the ADMX rats). Paired comparisons indicated that in both the Sham and the ADMX rats, the group trained with 0.64 - or $0.75-\mathrm{mA}$ shock had significantly higher retention scores than the group trained with $0.50-\mathrm{mA}$ shock $(0.64-$ or $0.75-\mathrm{mA}$ group vs. $0.50-\mathrm{mA}$ group: for the Sham rats, $U=35$ and 31 , respectively, $p<.05$; for ADMX rats, $U=19$ and 20 , respectively, $p<.01$; two-tailed tests). Differences between the 0.64$\mathrm{mA}$ group and the $0.75-\mathrm{mA}$ group were not significant.

The effect of adrenal demedullation was examined by comparing Sham and ADMX rats trained with identical shock intensity. In the groups given $0.50-$ or $0.64-\mathrm{mA}$ shock, the retention latencies of the ADMX rats were significantly lower than those of the Sham controls $(U=41$, $p<.01$, for 0.50 -mA groups; $U=36, p<.05$, for 0.64-mA groups). There was no difference in the retention latencies of the Sham and the ADMX rats given 0.75 mA shock.

\section{EXPERIMENT 2}

\section{Procedure}

The second experiment investigated the effect of ST lesions on retention of responses trained under various intensities of footshock. Rats received ST lesions (ST-) or sham ST operations $(\mathrm{ST}+$ ) as described in the General Method section. The training footshock intensities in the inhibitory avoidance task were $0.75,1.0$, or $1.5 \mathrm{~mA}$ for $0.5 \mathrm{sec}$. These footshock parameters were chosen on the basis of the findings of Experiment 1 as well as our previous findings (Liang \& McGaugh, 1983b) that ST sham-operated rats have poor retention when trained with a footshock intensity of $0.70 \mathrm{~mA}$.

\section{Results}

The retention performance of the ST + and ST - groups in the inhibitory avoidance task as well as the number of subjects in each group are shown in Figure 2. Higher intensity of footshock appeared to produce better retention scores. Although Kruskal-Wallis one-way analyses of variance failed to reveal significant effects among either the ST + groups or the ST - groups, paired comparisons indicated that for ST - rats, the retention latencies of the group given $0.75-\mathrm{mA}$ footshock were significantly lower than those of the group given $1.5-\mathrm{mA}$ shock $(U=26$, $p<.05$, two-tailed). 


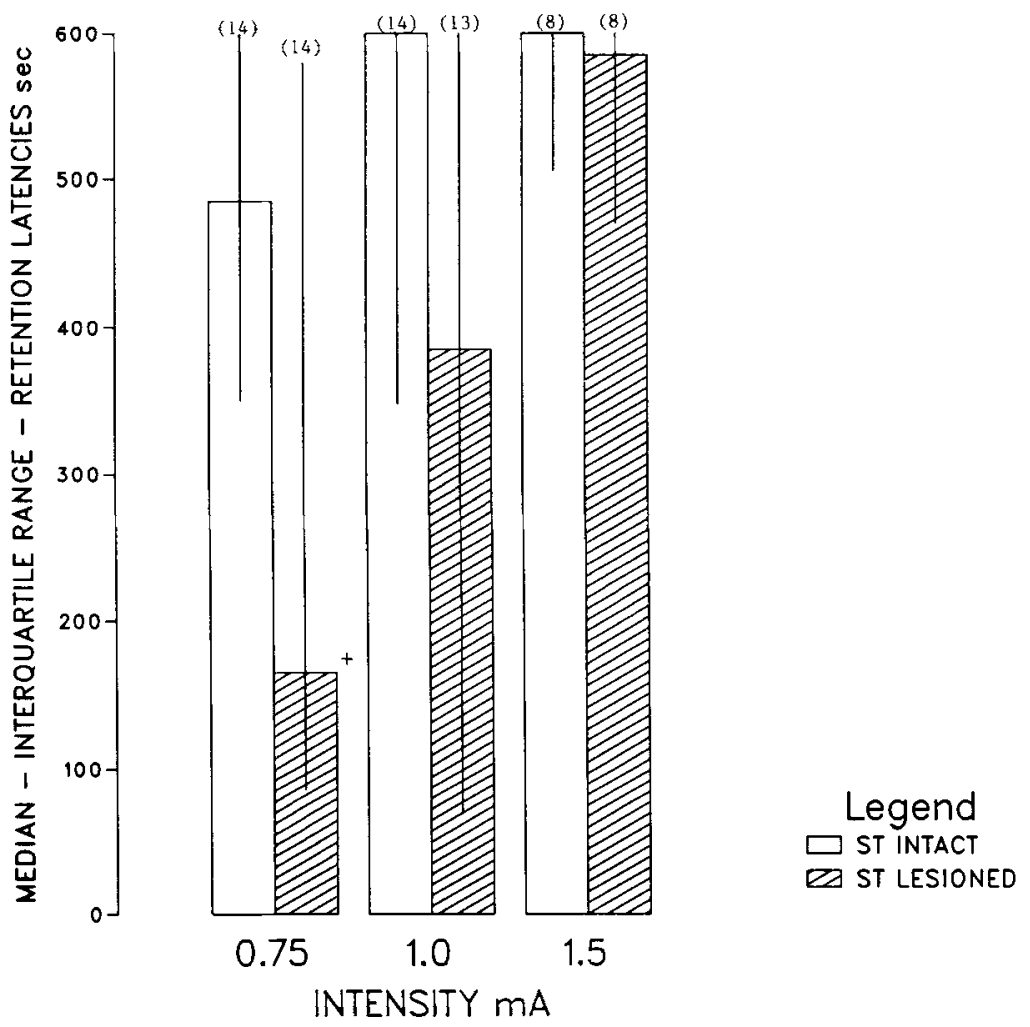

Figure 2. Effects of the stria terminalis (ST) lesions on inhibitory avoidance retention under various training footshocks. $+=.05<p<.075$ different from the ST shamoperated groups.

To examine the ST-lesion effect, we compared retention performance of the ST + rats and the ST - rats given the same training footshock. Although, at all shock intensities, the ST + rats appeared to have higher retention scores than the ST - rats, only the difference in the 0.75 $\mathrm{mA}$ shock groups approached statistical significance $(U=57.5, .05<p<.075$, two-tailed tests).

Thus, the present findings indicate that ST lesions produce only a marginally significant retention impairment. These findings are comparable to those of our previous studies (Liang \& McGaugh, 1983a, 1983b; McGaugh et al., 1986), in which we found that lesions of the ST did not impair retention performance in avoidance tasks. On the basis of our previous findings that adrenal demedullation potentiated the otherwise nonsignificant amnestic effect of amygdala electrode implantation, we investigated, in Experiment 3, the combined effects of ST lesions and adrenal demedullation.

\section{EXPERIMENT 3}

\section{Procedure}

The third experiment examined the possible cooperative effect of combined ST lesions and adrenal demedullation on retention performance. Rats received one of the following sets of treatments: sham ST operation plus sham adrenal operation (ST +/Sham), ST lesions plus sham adrenal operation (ST - /Sham), sham ST opera- tion plus adrenal demedullation (ST +/ADMX), and ST lesions plus adrenal demedullation (ST - /ADMX). These four groups of animals were trained on the inhibitory avoidance task as described in the General Method section. According to our previous findings (Bennett et al., 1985; Liang et al., 1985), the effect on retention of combined amygdala and adrenal treatments was most readily demonstrated under 1.0-mA footshock in the inhibitory avoidance task. Furthermore, since, under this shock intensity, neither adrenal demedullation nor ST lesions produced a significant effect, on the basis of the present and previous findings, the retention deficit of the ST-/ADMX group, if observed, could be clearly attributed to a comparative effect of the two treatments. Therefore, the shock parameters set for the inhibitory avoidance task in the present study were $1.0 \mathrm{~mA}, 0.5 \mathrm{sec}$.

\section{Results}

Retention performance of various groups in the inhibitory avoidance task and the number of subjects in each group are shown in Figure 3. As can be seen, adrenal demedullation failed to affect retention. In both the ST+ and ST - groups, the retention scores of the Sham rats were not significantly different from those of the ADMX rats. Furthermore, adrenal demedullation failed to influence the effect of ST lesions on retention. In both the Sham and the ADMX groups, the ST + rats tended to have higher retention scores than the ST - rats, although in both cases the differences only approached statistical significance $(U=89$ and 79 for the Sham and the ADMX groups, respectively; .05 $<p<.075$, two-tailed). 

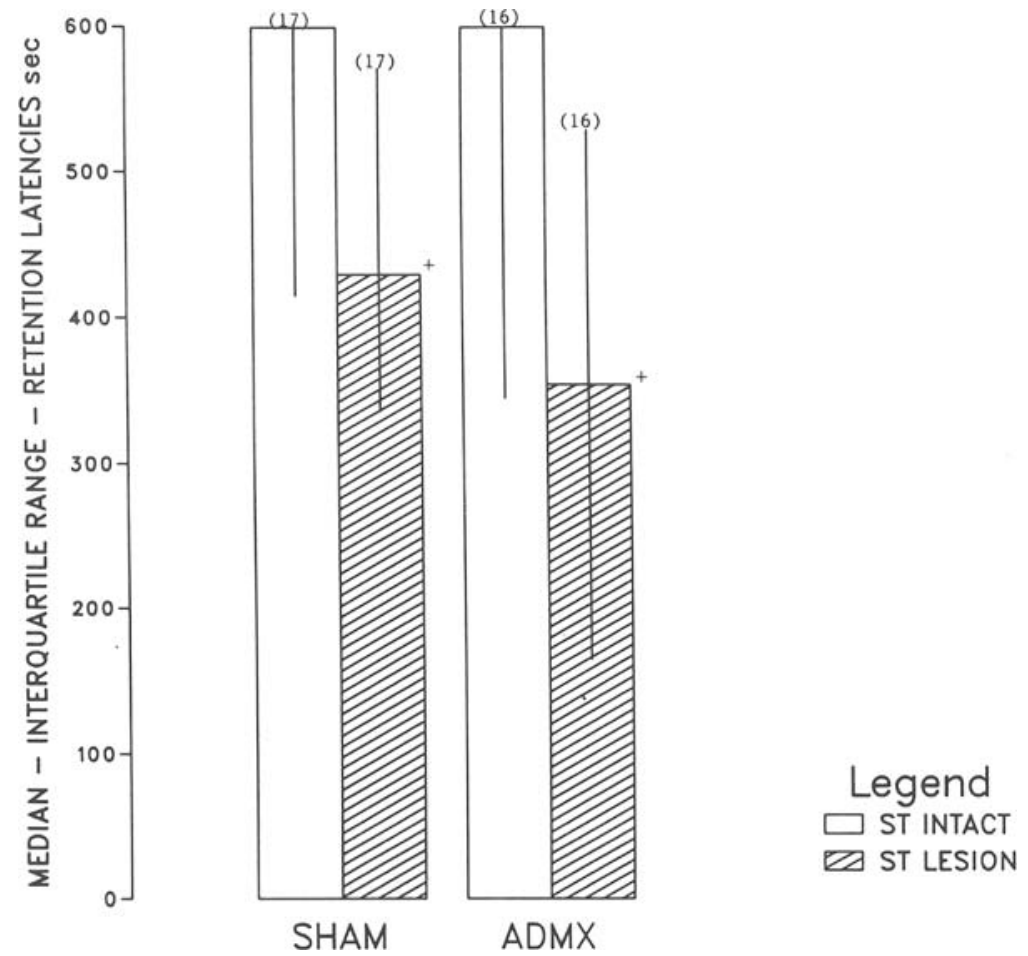

Figure 3. Efiects of the stria terminalis (ST) lesions and adrenal demedullation (ADMX) on inhibitory avoidance retention. $+=.05<p<.075$ different from the ST shamoperated groups.

Nevertheless, the ST-/ADMX group had significantly lower retention scores than the $\mathrm{ST}+/ \mathrm{Sham}$ group ( $U=73, p<.05$, two-tailed).

In summary, the present results indicated that lesions of the ST produced a mild, if any, retention deficit in the inhibitory avoidance task. This marginal impairment was not potentiated by removal of the adrenal medulla.

\section{HISTOLOGICAL AND CHEMICAL VERIFICATION}

Typical lesions of the ST are shown in Figure 4. Animals were excluded from the data analyses if lesions completely missed any one of the STs. A total of 14 animals were discarded for this reason.

Data from two ADMX rats were discarded because their adrenals had more than $10 \%$ of catecholamine of the sham-operated adrenal glands. For the ADMX rats included in the analyses, the surgery depleted about $97 \%-99 \%$ of adrenal catecholamines. The mean epinephrine and norepinephrine per pair of glands in the Sham animals were $10.94 \pm 1.99 \mu \mathrm{g}$ and $39.20 \pm 1.88 \mu \mathrm{g}$, respectively; those in the ADMX rats were $0.10 \pm 0.07 \mu \mathrm{g}$ and $0.69 \pm 0.66 \mu \mathrm{g}$, respectively.

\section{DISCUSSION}

Several findings emerge from the present experiments: First, removal of the adrenal medulla impaired retention in the inhibitory avoidance task. This impairing effect appeared only under low-footshock conditions $(0.50$ and $0.64 \mathrm{~mA}$ ). Second, lesions of the ST produced, at most, a marginal retention deficit in the inhibitory avoidance task with 0.75 - or 1.0-mA footshocks (Experiments 2 or 3 , respectively). Third, combined administration of ST lesions and adrenal demedullation failed to potentiate the effect of ST lesions (at a 1-mA training footshock condition).

In the present study, adrenal and ST surgeries were performed prior to training, and thus their effects on reten-

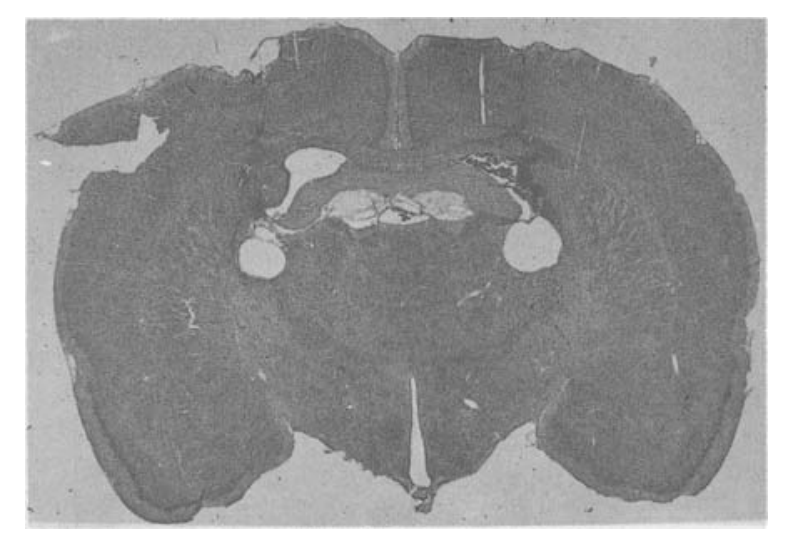

Figure 4. Bilateral lesions of the stria terminalis in a typical animal. 
tion performance might be due to influences on acquisition. However, this seems unlikely in view of our previous findings that neither adrenal demedullation nor ST lesions affect acquisition performance in an active avoidance task (Bennett et al., 1985; Liang \& McGaugh, 1983a). Furthermore, ST lesions do not affect performance in an open-field exploratory task (Liang \& McGaugh, 1983a).

The most significant findings of the present study are that adrenal demedullation induced a retention deficit under low-footshock training conditions but not under highfootshock conditions. These findings reconcile the conflicting results from previous studies. In two studies reporting lack of a demedullation effect on retention (Moyer \& Bunnell, 1959; Silva, 1973), animals received intense training footshock (1.0 mA by Silva and $1.4 \mathrm{~mA}$ by Moyer and Bunnell). On the other hand, Borrell et al. (1983) and Caldwell (1962), who trained their animals with milder footshock ( 0.5 and $0.2 \mathrm{~mA}$, respectively), observed a significant retention deficit in the ADMX animals. Borrell et al. (1983) also found that the retention deficit observed $48 \mathrm{~h}$ after adrenalectomy, which is due to depletion of epinephrine, appeared only under lowfootshock training. Thus, the present findings, in congruence with previous ones, provide additional support for the conclusion that task parameters are important in determining the influences on memory-formation processing (Gold et al., 1975; Sternberg et al., 1983).

Consistent with previous evidence that exogenous administration of epinephrine enhances memory (Gold \& van Buskirk, 1978; Introini-Collison \& McGaugh, 1986; Liang et al., 1985; Sternberg et al., 1985) and that adrenal demedullation attenuated the memory-enhancing effect of amphetamine, 4-OH-amphetamine, and naloxone (Martinez, Vasquez, et al., 1980; Zhang, McGaugh, Juler, \& Introini-Collison, in press), the amnesia seen in ADMX rats suggests that adrenal epinephrine may play an important role in influencing memory processing. The lack of an amnestic effect of adrenal demedullation under highfootshock training conditions may be due to superfluous release of other memory-modulatory hormones, such as adrenocorticotropin, which could compensate for the lack of epinephrine (Izquierdo, 1984). Since previous studies have shown that injections of epinephrine shortly after high-footshock training impair rather than enhance retention performance (Gold \& van Buskirk, 1978), removal of the adrenal medulla prior to high-footshock training may reduce a deleterious influence on retention. The findings that adrenal demedullation attenuates the learningimpairing effect of peripherally administered met- and leuenkephalin (Martinez, Rigter, \& van der Gugten, 1980; Zhang et al., in press) are consistent with this interpretation.

In the present study, animals with ST lesions had slightly lower retention scores under certain conditions (Experiments 2 and 3). However, the effect did not reach statistical significance. The lack of a clear amnestic effect of ST lesions might have been due to a slight increase in footshock sensitivity in the ST-lesioned rats (Liang \&
McGaugh 1983b). The present results, although consistent with our previous findings (McGaugh et al., 1986; Liang \& McGaugh, 1983a, 1983b), contrast with those of Ross and Grossman (1977), who demonstrated a retention deficit in ST-lesioned rats trained in a multiple-trial inhibitory avoidance task. Whether the difference in the training paradigm (one vs. multiple training trials) underlies the discrepant results remains to be resolved.

The lack of a robust ST lesion effect on retention does not exclude a role for the ST in memory modulation. Previous findings have shown that lesions of the ST attenuated the amnestic effect of electrical amygdala stimulation (Liang \&McGaugh, 1983b), the retention-enhancing effect of peripherally administered epinephrine (Liang \& McGaugh, 1983a), ACTH4-10 (van Wimersma Greidanus et al., 1979), naloxone (McGaugh et al., 1986), and the retention-impairing effect of $\beta$-endorphin (McGaugh et al., 1986). Therefore, functional integrity of the ST appears to be essential for various modulatory influences on memory-storage processing.

The findings of Experiment 3 indicate that ST lesions and adrenal demedullation in combination did not potentiate the effect of ST lesions on retention. These results contrast with our previous findings that amygdala electrode implantation and adrenal demedullation combined produced a retention deficit that was not seen in animals given only one of these surgical treatments (Bennett et al., 1985). The procedure of implanting an amygdala electrode damages other brain tissues, including the caudateputamen. Therefore, the impact of amygdala electrode implantation on memory processing may not necessarily be comparable to that of ST lesions. Conversely, these discrepant findings suggest that the memory modulatory function of the amygdala may not be mediated entirely through the ST. Evidence further supporting this notion is that while ST lesions produce, at best, only slight retention impairment, lesions of the amygdala produce a profound retention deficit (Liang et al., 1982). The role of the amygdala, the ST, and other amygdala pathways, such as the ventral amygdalofugal pathway in memory formation processing, requires further elucidation.

\section{REFERENCES}

Bennett, C., Liang, K. C., \& McGaugh, J. L. (1985). Depletion of adrenal catecholamines alters the amnestic effect of amygdala stimulation. Behavioural Brain Research, 15, 83-91.

Borrell, J., De Kloet, E. R., Versteeg, D. H. G., \& Bohus, B. (1983). Inhibitory avoidance deficit following short-term adrenalec tomy in the rat: The role of adrenal catecholamines. Behavioral \& Neural Biology, 39, 241-258.

Caldwell, D. F. (1962). Effects of adrenal demedullation on retention of a conditioned avoidance response in the mouse. Journal of Comparative \& Physiological Psychology, 55, 1079-1081.

Ellis, M. E., \& KESNer, R. P. (1983). The noradrenergic system of the amygdala and aversive memory processing. Behavioral Neuroscience, 97, 399-415.

Gallagher, M., KapP, B. S., Pascoe, J. P., \& RapP, P. R. (1981). A neuropharmacology of amygdaloid systems which contribute to learning and memory. In $\mathrm{Y}$. Ben-Ari (Ed.), The amygdaloid complex (pp. 343-354). Amsterdam: Elsevier/North-Holland. 
Gold, P. E., Hankins, L., Edwards, R. M., Chester, J., \& MCGAUGH, J. L. (1975). Memory interference and facilitation with posttrial amygdala stimulation: Effect on memory varies with footshock level. Brain Research, 86, 509-513.

Gold, P. E., MACRI, J., \& MCGaugh, J. L. (1973). Retrograde amnesia produced by subseizure amygdala stimulation. Behavioral Biology, 9, 671-680.

Gold, P. E., McCarty, R., \& Sternaerg, D. B. (1982). Peripheral catecholamines and memory modulation. In C. A. Marsan \& H. Matthies (Eds.), Neuronal plasticity and memory formation. New York: Raven Press.

Gold, P. E., \& MCGaugh, J. L. (1977). Hormones and memory. In L. H. Miller, C. A. Sandman, \& A. J. Kastin (Eds.), Neuropeptide influences on brain and behavior (pp. 127-143). New York: Raven Press.

Gold, P. E., \& VAN BuskIRK, R. (1978). Posttraining brain norepinephrine concentrations: Correlation with retention performance of avoidance training with peripheral epinephrine modulation of memory processing. Behavioral Biology, 23, 509-520.

GolD, P. E., \& ZORNETZER, S. F (1983). The mnemon and its juices: Neuromodulation of memory processes. Behavioral \& Neural Biology, 38, 151-189.

Introini-Collison, I. B., \& McGaugh, J. L. (1986). Epinephrine modulates long-term retention of an aversively-motivated discrimination task. Behavioral \& Neural Biology, 45, 358-365.

IZQUIERDO, I. (1984). Endogenous state dependency: Memory depends on the relation between the neurohumoral states present after training and the time of testing. In G. Lynch, J. L. McGaugh, \& N. M. Weinberger (Eds.), Neurobiology of learning and memory (pp. 333350). New York: Guilford Press.

Liang, K. C., Bennett, C., \& McGaugh, J. L. (1985). Peripheral epinephrine modulates the effects of posttraining amygdala stimulation on memory. Behavioural Brain Research, 15, 93-100.

LiANG, K. C., Juler, R., \& McGaugh, J. L. (1986). Modulating effects of posttraining epinephrine on memory: Involvement of the amygdala noradrenergic system. Brain Research, 368, 125-133.

Liang, K. C., \& MCGaugh, J. L. (1983a). Lesions of the stria terminalis attenuate the amnestic effect of amygdaloid stimulation on avoidance responses. Brain Research, 274, 309-318.

Liang, K. C., \& McGaugh, J. L. (1983b). Lesions of the stria terminalis attenuate the enhancing effect of posttraining epinephrine on retention of an inhibitory avoidance response. Behavioural Brain Research, 9, 49-58.

Liang, K. C., McGaugh, J. L., Martinez, J. L., Jr., Jensen, R. A., VASQuez, B. J., \& Messing, R. B. (1982). Posttraining amygdaloid lesions impair retention of an inhibitory avoidance response. $B e-$ havioural Brain Research, 4, 237-249.

Liang, K. C., Messing, R. B., \& McGaugh, J. L. (1983). Naloxone attenuates amnesia caused by amygdaloid stimulation: The involvement of a central opioid system. Brain Research, 271, 41-49.

Martinez, J. L., JR., Ishikawa, K., Liang, K. C., Jensen, R. A., Bennett, C., Sternberg, D. B., \& McGaugh, J. L. (1983). 4-OH amphetamine enhances retention of an active avoidance response in rats and decreases regional brain concentrations of norepinephrine and dopamine. Behavioral Neuroscience, 97, 962-969.

Martinez, J. L., JR., Rigter, H., \& VAN der Gugten, J. (1980). Enkephalin effects on avoidance conditioning are dependent on the adrenal glands. In E. Stark, G. B. Makara, Zs. Acs, \& E. Endroczi (Eds.), Endocrinology, neuroendocrinology, neuropeptides (Vol. 13, pp. 273-277). Budapest: Pergamon/Akademia: Kiado.

Martinez, J. L., JR., Vasquez, B. J., Rigter, H., Messing, R. B., Jensen, R. A., Liang, K. C., \& McGaugh, J. L. (1980). Attenuation of amphetamine-induced enhancement of learning by adrenal demedullation. Brain Research, 195, 433-443.
McGaugh, J. L. (1983). Hormonal influences on memory. Annual Review of Psychology, 34, 297-323.

McGaugh, J. L., Introini-Collison, I. B., Juler, R. G., \& IzQUIERDO, I. (1986). Stria terminalis lesions attenuate the effects of posttraining naloxone and b-endorphin on retention. Behavioral Neuroscience, 100, 839-844.

Mishkin, M., Malamut, B., \& Bachevalier, J. (1984). Memories and habits: Two neural systems. In G. Lynch, J. L. McGaugh, \& N. M. Weinberger (Eds.), Neurobiology of learning and memory. New York: Guilford Press.

MoYer, K. E., \& BUNNELl, B. N. (1959). Effect of adrenal demedullation on an avoidance response in the rat. Journal of Comparative \& Physiological Psychology, 52, 215-216.

Novack, G., Sterneerg, D. B., \& McGaugh, J. L. (1984). Role of $\mathrm{a}$ - and b-adrenergic receptors in learning and memory in mice. Neuroscience Abstracts, 10, 254.

OGREN, S.-O., \& FUXE, K. (1977). On the role of brain NA and the pituitary-adrenal axis in avoidance learning: I. Studies with corticosterone. Neuroscience Letters, 5, 291-296.

Roberts, D. C. S., \& Fibiger, H. C. (1976). Conditioned taste aversion induced by diethyldithiocarbamate (DCC). Neuroscience Letters, 2, 339-342.

Ross, J. F., \& Grossman, S. P. (1977). Transections of stria medullaris or stria terminalis in the rat: Effects of aversively controlled behavior. Journal of Comparative \& Physiological Psychology, 70, 907-915.

SARTER, M., \& MARKowitsch, H. J. (1985). Involvement of the amygdala in learning and memory: A critical review, with emphasis on anatomical relations. Behavioral Neuroscience, 99, 342-380.

SilvA, M. T. A. (1973). Extinction of a passive avoidance response in adrenalectomized and demedullated rats. Behavioral Biology, 9, 553-562.

SiLVA, M. T. A. (1974). Effects of adrenal demedullation and adrenalectomy on an active avoidance response of rats. Physiological Psychology, 2, 171-174.

SternberG, D. B., Gold, P. E., \& MCGaugh, J. L. (1983). Memory facilitation and impairment with supraseizure electrical brain stimulation: Attenuation with pretrial propranolol injections. Behavioral \& Neural Biology, 38, 261-268.

Sternberg, D. B., Issacs, K., Gold, P. E., \& McGaugh, J. L. (1985). Epinephrine facilitation of appetitive learning: Attenuation with adrenergic receptor antagonists. Behavioral \& Neural Biology, 44, 447-453.

Sternberg, D. B., Korol, D., Novack, G. D., \& McGaugh, J. L. (1986). Epinephrine-induced memory facilitation: Attenuation by adrenergic receptor antagonist. European Journal of Pharmacology, 129, 189-193.

van Wimersma Greidanus, T., Croiset, G., Bakker, E., \& BouMAN, H. (1979). Amygdaloid lesions block the effect of neuropeptides (vasopressin, ACTH4-10) on avoidance behavior. Physiology \& Behavior, 22, 291-295.

Walsh, T. J., \& Palfai, T. (1979). Peripheral catecholamines and memory: Characteristics of syrosingopine-induced amnesia. Pharmacology, Biochemistry \& Behavior, 11, 449-452.

Zhang, S., McGaugh, J. L., Juler, R. G., \& Introini-Collison, I. B. (in press). Naloxone and met-enkephalin effects on retention: Attenuation by adrenal denervation. European Journal of Pharmacology.

(Manuscript received December 1, 1986; Revision accepted for publication March 10, 1987.) 